\title{
Biochemical Composition and Fatty Acid, Amino Acid Analysis of Cymadusa Filosa (Amphipod; Gammarids) in the Red Sea-Egypt
}

\author{
Mohamed M. A. Zaid', Fatma A. Abdel Razek', El Sayed A. E. Hamed ${ }^{3}$, \\ Tarek A. A. Mohammed ${ }^{* 3}$, Hamdy O. Ahmed ${ }^{* 2}$ \\ ${ }^{1}$ Faculty of Science, Al-Azhar University, Cairo, Egypt \\ ${ }^{2}$ National Institute of Oceanography and Fisheries, Alexandria, Egypt \\ ${ }^{3}$ National Institute of Oceanography and Fisheries, Hurghada, Egypt \\ hamdy_nfra@yahoo.com
}

\begin{abstract}
This part of the current study concerned with the growth analysis of the major biochemical elements in C. filosa (Crustacea: Amphipoda) reared in the laboratory aiming to indicate its nutritional value as life feed, the results clear that adults individuals, which has been breeding in the laboratory and also juvenile's, Contain high levels of total protein, total lipid, than individuals collected from the field, while total sugar ratio was in the field is higher than individuals in the laboratory. The main reason that its nutrition through different species of microalgae which contain high ratio of nutritional value. In adult cultured the highest value of essential than value nonessential of amino acids but The culture of juvenile's the highest value of nonessential than value of essential amino acids.
\end{abstract}

The level of polyunsaturated fatty acids ( $\mathrm{n}-6$ PUFA) in adult cultured and juvenile's culture $(0.69 \mathrm{mg} / \mathrm{g})$ higher than field sample $(0.50 \mathrm{mg} / \mathrm{g})$, and The total level of saturated fatty acids (SFA) in cultured adult is (105.61 $\mathrm{mg} / \mathrm{g}$ ) higher than culture juvenile's $(99.17 \mathrm{mg} / \mathrm{g})$ and field sample $(15.98 \mathrm{mg} / \mathrm{g})$

Keywords: Cymadusa filosa, adult, juvenile's, field, fatty acids, amino acids

\section{INTRODUCTION}

The availability of appropriate and economical feed is one of the most important factors in aquaculture (Chen \& Long, 1991). As aquaculture developed, live feed has often been a bottleneck in the larviculture of many species of fish and shellfish, especially at times when upscaling from laboratory and pilot trials to large industrial units (Støttrup \& McEvoy, 2003).

Amphipods (gammarids and caprellids) are among the most adaptable species in the world (Woods, 2009). Ampithoids are shallow-water tropical to temperate herbivorous amphipods found around the world. Previous

To this study 42 ampithoid species were known from Australia (Just 2002; Lowry \& Stoddart 2003; Peart 2004; Peart 2006; Peart 2007a) we report 19 species in five genera from the Great Barrier Reef and increase the Australian ampithoid fauna to 49 species. About $75 \%$ of the 19 Great Barrier Reef ampithoid species,

Cymadusa filosa sensu lato has been reported many times from various localities and by many authors. (Barnard and Karaman 1991) categorized it as a pantropical species. There are records of this species from the Mediterranean Sea, the Atlantic coast of Africa, the east and west coast of South Africa, Madagascar, the Seychelles, the Red Sea, Sokotra, India, Hawaii, New Caledonia, the east and west coast of Australia, and Brazil. The taxonomic status of Cymadusa filosa sensu lato is in a state of confusion and misinterpretation.

a complete replacement of the marine resources for feed in mariculture is unlikely because most cold blooded animals suitable for mariculture depend on dietary long-chain highly unsaturated fatty acids (HUFA, with $\geq 3$ double bonds and $\geq 20$ carbon chain length), and most freshwater and brackish species required generally less HUFA in their diets than carnivore marine fish (Glencross, 2009 and Tocher 2010). (Guerra-García et al., 2004) of the fatty acid composition of nine caprellid species from the Strait of Gibraltar represents the most comprehensive study to date. They found caprellids to contain relatively high levels of polyunsaturated fatty acids (up to $50 \%$ of all fatty acids) particularly 
EPA and DHA; the saturate palmitic acid, 16:0, and the monounsaturated oleic acid, 18:1n-9 were other major fatty acids. Overall, fatty acids were similar in all species,

(Shaban 2012) The analysis of the composition of Caprella mutica from Caprellidea collected from the field Oregon State, USA. In the marina was slightly higher total protein and of cultured samples less content averaged dry weight in the cultured sample.

(Sushchik et al., 2003) emphasized that PUFA content is only one aspect for an estimation of the food quality. The high level of total phenolic and flavonoid indicated high antioxidant activities (Ghasemzadeh et al., 2010).

This amino acid is important as a stress response indicator (Leroy et al., 2010) and plays a crucial role in managing oxidative stress (Matés et al., 2002). Amino acids are essential for several functions including energy production, osmoregulation and muscle growth (Karanova and Andreev, 2010)

The aim of the study the biochemical composition for individuals from field sample, Culture (adult, juveniles) for analyses such as total sugar, Total protein, and Total lipid, Total phenolics, Total flavanoids, amino acids composition, Fatty acid to explain the nutritional value Interesting rearing gammaridea amphipods species $C$. filose

\section{MATERIALS AND MethodS}

\subsection{Collection of Sample}

Field samples from amphipod species Cymadusa filosa Savigny, (1816) were collected from the coastal zone the National Institute of Oceanography and Fisheries (NIOF) $\left(27^{\circ} 17^{\prime} 09 \mathrm{~N}, 33^{\circ} 46^{\prime} 07 \mathrm{E}\right)$ in Hurghada - Red Sea figure (1) were collected and separated from marine algae. As for the samples adult cultured, and was reared in the laboratory and feed with different types of micro-algae Nannochloropsis $s p$, Tetraselmis $s p$, as for the juveniles culture samples, Hatched in a laboratory and feed with different types of micro-algae.

Laboratory experiment was in the summer season and for the physical factors, the temperature was between $28-30^{\circ} \mathrm{C}$ degrees and salinity between $\% 039-\% 040$ per thousand and $\mathrm{P} \mathrm{H}=8$, field Sample collection in the summer season, The experimental period of 60 days.

As for the sample sizes adult Individuals up to 0.8 to $1.4 \mathrm{~cm}$, and juveniles reach a length of $0.2-0.4$ $\mathrm{cm}$, The color of organism: - Light Grey

Laboratory analysis was in the National Institute of Oceanography and Fisheries in Alexandria (Central Laboratory).

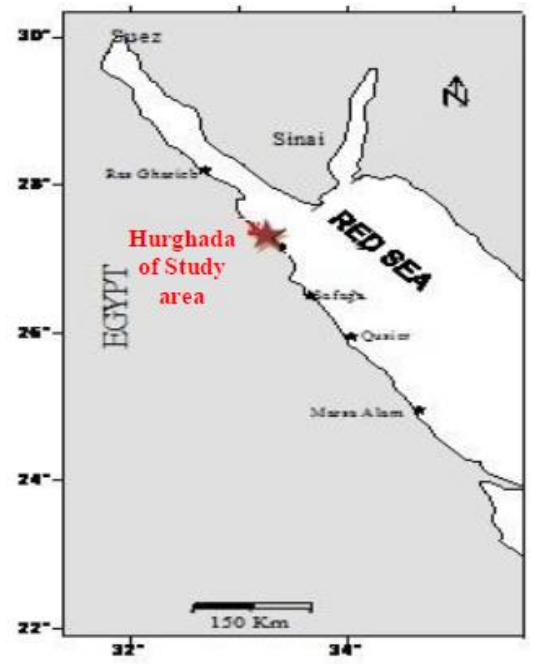

Figure1. Map and diagrammatic sketch showing the area of study north to Hurghada in front of the National Institute of Oceanography and Fisheries (NIOF), Red Sea Branch.

\subsection{Water Content}

For water content determination, freshly collected individuals measured from 1 to $2 \mathrm{~cm}$ length were grouped into 20 to 30 individuals. Specimens were placed on a glass-fiber filter in a petri dish and weighted using an electronic micro-balance (wet weight). After that, the specimens in petri dish were 
Biochemical Composition and Fatty Acid, Amino Acid Analysis of Cymadusa Filosa (Amphipod; Gammarids) in the Red Sea-Egypt

dried at $60{ }^{\circ} \mathrm{C}$ for 48 to $72 \mathrm{~h}$. After cooling to room temperature, Petri dishes containing specimens were individually weighed (dry weight) and then the water content of Cymadusa filosa can estimated from the following equation

\section{$\%$ of water content $=$ wet weight - dry weight $/$ wet weight $\times 100$}

The other biochemical analysis were done according to the methods In Table (1) according to their sources

Table1. method used of biochemical analysis of C. filosa

\begin{tabular}{|c|c|c|}
\hline No & Tvne of analvsis & Method used \\
\hline 1 & Determination of total proteins:- & Described by (Gornall et al. 1949) \\
\hline 2 & Determination of total lipid:- & Described by (Zollner and kirsch 1962) \\
\hline 3 & Total fatty acids:- & Described by (Duncombe 1962) \\
\hline 4 & Total sugar:- & The total sugar was assaved as described by (Tinder 1969) \\
\hline 5 & Determination of total phenolic:- & Determined by the method of (Taga et al. 1984) \\
\hline 6 & Determination of total & Determined by a colorimetric method of (Zhishen et al., 1999) \\
\hline 7 & Determination ofamino acid:- & $\begin{array}{l}\text { The amino acid determined by amino acid analyzer (DIONEX- } \\
\text { ICS 3000) }\end{array}$ \\
\hline 8 & Fatty acids composition:- & $\begin{array}{l}\text {-Lipid extraction The method of (AOAC 2000) } \\
\text {-Separation of fatty acids (Vogel, 1975) } \\
\text {-Preparation of diazomethane by (Vogel 1975) } \\
\text {-Methylation of fatty acids with diazomethane } \\
\text {-Sources of standard fatty acids from C 08:0 to C 22:0 } \\
\text {-Identification and determination of fatty acids by gas liquid } \\
\text { chromatography The method described by (Farag et al. 1986) } \\
\text {-Fraction of unsaponifiables }\end{array}$ \\
\hline
\end{tabular}

\section{ReSUlts}

\subsection{A-Water Content}

The level of total water and ashing in table (2) showed the total water and ashing in adults cultured respectively $32 \%, 5 \%$ high than field sample $16 \%, 3 \%$ and culture juveniles $2 \%, 1 \%$.

\subsection{B-Total Sugar}

The total level of sugar in samples collected from the field high than adults cultured and juveniles data in table (2) showed total sugar contents in the tissue of cultured C. filose., where in adults the result less than $1.6 \mathrm{mg} / \mathrm{dl}$ and in juveniles $1.2 \mathrm{mg} / \mathrm{dl}$, the total sugar in the samples collected from the field was slightly higher recorded $4.41 \mathrm{mg} / \mathrm{dl}$.

\subsection{C-Total Protein}

The total level of protein in adults cultured and juveniles are high than samples collected from the field data in table (2) showed that where the total protein contents in the tissue of adults cultured $C$. filosa which recorded $1.62 \mathrm{mg} / \mathrm{dl}$ where juveniles $0.84 \mathrm{mg} / \mathrm{dl}$. While, the total protein in the samples collected from the field was slightly less $0.44 \mathrm{mg} / \mathrm{dl}$.

\subsection{D-Total Lipid}

The total level of lipid in adults cultured and juveniles are high than samples collected from the field data in table (2) indicated that total lipid contents in the tissue of cultured C. filosa in adults were higher $24.59 \mathrm{mg} / \mathrm{dl}$ where juveniles $40.98 \mathrm{mg} / \mathrm{dl}$. Mean while, the total lipid in the samples collected from the field was slightly less being from $6.145 \mathrm{mg} / \mathrm{dl}$.

\subsection{E-Total Poly Phenolic Content}

\subsubsection{Total Phenolic}

Data in table (2) where the result showed that total phenolics in adult cultured $0.8419 \mathrm{mg} / \mathrm{g}$, where juvenile's $0.4467 \mathrm{mg} / \mathrm{g}$. the total phenolics in the samples collected from the field were slightly less $0.378 \mathrm{mg} / \mathrm{g}$. 


\subsubsection{Total Flavanoids}

Data in table (2) where the result showed that total flavanoids in adult cultured $18.5 \mathrm{mg} / \mathrm{g}$, where juvenile's $11.66 \mathrm{mg} / \mathrm{g}$. the total flavanoids in the samples collected from the field $16.6 \mathrm{mg} / \mathrm{g}$.The total level of phenolics and phenolics contents in the tissue of adult cultured are high than juveniles and samples collected from the field

Table2. composition of major total sugar, total protein, total lipid, and total free fatty acids TFFA, total phenolics and total flavanoids performed for cultured and field collected $C$. filosa.

\begin{tabular}{|l|l|l|l|}
\hline Parameter & Field sample & Adult culture & Juveniles culture \\
\hline Total water content $\%$ & $16 \%$ & $32 \%$ & $2 \%$ \\
\hline Total ashing $\%$ & $3 \%$ & $5 \%$ & $1 \%$ \\
\hline Total sugar mg/dl & 4.41 & 1.6 & 1.2 \\
\hline Total protein mg/dl & 0.44 & 1.62 & 0.84 \\
\hline Total lipid mg/dl & 6.145 & 24.59 & 40.98 \\
\hline Total free fatty acids TFFA mg/dl & 3106.224 & 4235.76 & 3529.8 \\
\hline Total phenolics $(\mathrm{mg} / \mathrm{g})$ & 0.378 & 0.8419 & 0.4467 \\
\hline Total Flavanoids $(\mathrm{mg} / \mathrm{g})$ & 16.6 & 18.5 & 11.66 \\
\hline
\end{tabular}

\subsection{F-Amino Acids Composition}

\subsubsection{Classify Amino Acids}

Amino acids is classified, into the essential and the nonessential, the essential including on six types from amino acids (Lysine, Threonine, Leucine, Methionine, Phenylalanine, and Histidine). The nonessential including on seven types from amino acids (Alanine, Glutamic acid, Tyrosine, Aspartic acid, Cystine, Serine, Glycine)

There is a difference in the number and amount of amino acids between each of the field sample, cultured adult, Culture juvenile's As follows:-

In field sample the highest value of nonessential than value of essential amino acids and in table (3), where the result showed the highest value in Histidine, Lysine, And less valuable in , Leucine, Phenylalanine Threonine, Methionine and but in non-essential contain the highest value in Aspartic acid, Glycine, and less valuable in Alanine, Tyrosine, Cystine, Serine

In adult cultured the highest value of essential than value Non-essential of amino acids table (4), where the result showed the highest value in Leucine, Phenylalanine and less valuable in Histidine, Lysine, Threonine, Methionine. But in nonessential contain the low value in Glutamic acid, Alanine and less valuable in Aspartic acid, Glycine, Tyrosine, Cystine, Serine in the culture of juvenile's the highest value of Nonessential than value of essential amino acids in table (4), where the result showed the highest value in Histidine, Methionine and less valuable in Leucine, Lysine, Phenylalanine, Threonine, but in nonessential contain the highest value in Alanine, Serine acid, and less valuable in Glycine

Table3. Essential amino acids analysis in field sample, Adult culture, Juveniles culture

\begin{tabular}{|c|c|c|c|c|}
\hline No & Essential $\mu \mathrm{M} / \mathrm{g}$ & Field sample & Adult culture & Juveniles culture \\
\hline 1 & Lysine & 849.27 & 1235.58 & 8527.23 \\
\hline 2 & Threonine & 26.28 & 35.55 & 304856.95 \\
\hline 3 & Leucine & 451.13 & 104199.65 & 10312546.16 \\
\hline 4 & Methionine & 27.25 & 60.47 & 12093526.11 \\
\hline 5 & Phenylalanine & 373.15 & 7555.92 & 107195.69 \\
\hline 6 & Histidine & 604.99 & 863.62 & 13154452.25 \\
\hline
\end{tabular}

Table4. Non-essential amino acids analysis in field sample, Adult culture, Juveniles culture

\begin{tabular}{|l|l|l|l|l|}
\hline No & Non-essential $\mu \mathrm{M} / \mathrm{g}$ & Field sample & Adult culture & Juveniles culture \\
\hline 1 & Alanine & 231.91 & 14757.87 & 90685099.05 \\
\hline 2 & Glutamic acid & n.d & 24304.73 & n.d \\
\hline 3 & Tyrosine & 286.25 & 534.45 & n.d \\
\hline 4 & Aspartic acid & 6219.66 & 9642.45 & n.d \\
\hline 5 & Cystine & 148.76 & 286.47 & n.d \\
\hline 6 & Serine & 244.25 & 736.51 & 8928.94 \\
\hline 7 & Glycine & 8694.17 & 7695.45 & 3521.15 \\
\hline
\end{tabular}


Biochemical Composition and Fatty Acid, Amino Acid Analysis of Cymadusa Filosa (Amphipod; Gammarids) in the Red Sea-Egypt

\subsection{G-Fatty Acid Composition}

Results of gas chromatographic analysis of fatty acid composition of C. filosa is presented in table (5) where the result was fatty acid was number (C atom) from $\mathrm{C} 8: 0$ to $\mathrm{C} 18: 1(\mathrm{n}-9)$ present in adult cultured, juvenile's culture and field sample.

The total level of saturated fatty acids (SFA) in cultured adult is $(105.61 \mathrm{mg} / \mathrm{g}$ ) higher than culture juvenile's $(99.17 \mathrm{mg} / \mathrm{g}$ ) and field sample $(15.98 \mathrm{mg} / \mathrm{g})$ in table (5) and, The total level of unsaturated fatty acids (MUFA) higher in juvenile's culture $(1.729 \mathrm{mg} / \mathrm{g})$ and adult cultured $(1.212 \mathrm{mg} / \mathrm{g})$ than field sample $(0.724 \mathrm{mg} / \mathrm{g}$.

In present study, the level of polyunsaturated fatty acids (n-6 PUFA) in adult cultured and juvenile's culture $(0.69 \mathrm{mg} / \mathrm{g})$ higher than field sample $(0.50 \mathrm{mg} / \mathrm{g})$. But the level of monounsaturated fatty acids (n-9) (MUFA) in cultured juveniles and culture adult respectively $(1.212 \mathrm{mg} / \mathrm{g}),(1.729 \mathrm{mg} / \mathrm{g})$ higher than field sample $(0.724 \mathrm{mg} / \mathrm{g})$.

Table5. Fatty acid composition of C. filosa held on 50 L aquarium for 6 months (adult culture, juveniles) compared with such composition analyzed in field collected C. filosa (field).

\begin{tabular}{|c|c|c|c|c|c|}
\hline $\mathrm{N}$ & $\begin{array}{c}\text { Examples of } \\
\mathrm{o}\end{array}$ & Saturated Fatty Acids & $\begin{array}{c}\text { Field sample } \\
\mathrm{mg} / \mathrm{g}\end{array}$ & $\begin{array}{c}\text { Culture adult } \\
\mathrm{mg} / \mathrm{g}\end{array}$ & Culture juveniles mg/g \\
\hline 1 & Octanoate & $\mathrm{C} 8: 0$ & 0.08 & 0.03 & 0.03 \\
\hline 2 & Dcanoate & $\mathrm{C} 10: 0$ & 0.03 & 0.06 & 0.13 \\
\hline 3 & Laurate & $\mathrm{C} 12: 0$ & 0.08 & 0.28 & 0.15 \\
\hline 4 & Myristate & $\mathrm{C} 14: 0$ & 0.19 & 0.57 & 0.35 \\
\hline 5 & Palmitate & $\mathrm{C} 16: 0$ & 1.89 & 8.91 & 5.08 \\
\hline 6 & Stearate & $\mathrm{C} 18: 0$ & 1.97 & 9.96 & 6.32 \\
\hline 7 & Arachidate & $\mathrm{C} 20: 0$ & 00 & 0.07 & 0.16 \\
\hline 8 & Behenate & $\mathrm{C} 22: 0$ & 11.75 & 85.73 & 86.95 \\
\hline 9 & Linolenate (PUFA) & $\mathrm{C} 18: 2(\mathrm{n}-6)$ & 0.50 & 0.69 & 0.69 \\
\hline 1 & Oleate (MUFA) & $\mathrm{C} 18: 1(\mathrm{n}-9)$ & 0.724 & 1.212 & 1.729 \\
\hline \multicolumn{2}{|c|}{ Total SFA } & 15.98 & 105.61 & 99.17 \\
\hline & \multicolumn{2}{|c|}{ Total USFA } & 1.22 & 1.90 & 2.42 \\
\hline
\end{tabular}

SFA: saturated fatty acids, PUFA: polyunsaturated fatty acids, MUFA: monounsaturated fatty

\section{DISCUSSION}

The results of total water contents of $C$. filosa from their natural habitats and juveniles Culture show less than adult individuals which reared in the laboratory, In contrast to (Shaban, 2012) where water contents in Caprella mutica total reared in the laboratory were higher in water content than fieldcollected samples.

Total carbohydrate content in the adults cultured and juveniles were very low compared to protein and lipid Agreed with (Vengadeshperumal, et al., 2010) Carbohydrate content has been very low in the copepod as compared to protein and lipid. These lower values of carbohydrate of copepods (wild) have been already reported by (Nageswara and Krupanidhi 2001) the low carbohydrate content observed could be due to the fact that glycogen is the useful stored carbohydrate in many marine animals. The utilization of carbohydrate glucose amine during the chitin synthesis in crustaceans may be prone to the decrease of carbohydrate level in the zooplankton (Vengadeshperumal, et al., 2010)

Protein is an important but expensive dietary requirement for the growth of aquarium fish. (Vengadeshperumal et al., 2010) the protein was found to be the major biochemical component in many invertebrates as cultured copepod, Acartia southwelli and Acartia centrura. The function of protein is an important energy reserve may be true for zooplankton having low lipid content. The present findings are in agreement with the earlier works of (Maruthanayagam and Subramanian 1999) .Where the value of total protein measured in the tissue of the field sample $C$. filosa was recorded less than result of feeding by microalgae. Microalgae are rich in proteins which confirm the result of total protein in the adults cultured and in juveniles. The analysis of the composition of Caprella mutica from Caprellidea collected from the field Oregon State, USA. In the marina was slightly higher total protein and of cultured samples less content averaged dry weight in the cultured sample (Shaban 2012). (Appadoo 2008), which indicate the high nutritional value of our work. 
Lipids constitute are the major constituents of living organic matter, involved in a variety of cellular function including membrane structure (phospholipids and glycolipids) and energy storage (triacylglycerols and wax esters) (Wainman and Smith 1997). The lipid content of tropical zooplankton when compared to temperate zooplankton is significantly low and it was proved by the findings of (Sreepada et al., 1992). In the present study, total lipid measured in the tissue of the field sample C. filosa was slightly less while in the adults cultured and in juveniles were higher. in contrast to the result of $C$. mutica collected from the field showed higher lipid contents than cultured $C$. mutica (Shaban, 2012), (Vengadeshperumal et al., 2010)

Phenolics hinder oxidative degradation of lipids and thereby enhance the excellence and nutritional value of food. Phenolics possess a wide spectrum of biochemical activities such as antioxidant, antimutagenic, anticarcinogenic as well as ability of modifying gene expression (Nakamura et al., 2003). Flavonoids are a group of polyphenolic compounds with known properties which include free Radical scavenging, inhibition of hydrolytic and oxidative enzymes and anti-inflammatory action (Frankel, 1995).

In the present study, the high level of total phenolic and flavonoid in adults cultured of $C$. filosa than samples collected from the field and juveniles cultured. The high level of total phenolic and flavonoid indicated high antioxidant activities (Ghasemzadeh et al., 2010). Due to its antioxidant properties it can interfere with the oxidative process by reacting with free radicals chelating, catalytic metals and also by acting as oxygen scavengers (Dreosti, 2002; Harborne and Turner, 1984)

In the present study: The total amount from essential and nonessential Amino acids higher in cultured adult than the juveniles and Field sample. This amino acid is important as a stress response indicator (Leroy et al., 2010) and plays a crucial role in managing oxidative stress (Matés et al., 2002). Amino acids are essential for several functions including energy production, osmoregulation and muscle growth (Karanova and Andreev, 2010). With similar findings which found decreased levels of amino acids in crustaceans in the wild possibly due to starvation- like conditions (Mente et al., 2010).

In the present study the total amount from glutamic acid (nonessential Amino acids) in cultured adult about $(24304.7308 \mu \mathrm{M})$, but not found in the field sample. In a study conducted with the larval dragonfly Aeshna cyanea, proline along with glutamine was found to be one of the main contributors of the free amino acid reserves used to meet energy demands during starvation (Herzog and Liappis, 1987).

In the present study the total amount from alanine (nonessential Amino acids) higher in cultured adult than the juveniles and field sample, Alanine is also an important osmolyte in crustaceans, essential for maintaining cellular ion balance (Abe et al., 1999). Thus, altered alanine metabolism could also result in an ionic imbalance in benthic amphipod Diporeia spp.In the present study: The total amount of Phenylalanine from essential amino acids higher in juveniles and cultured adult the than field sample. Phenylalanine is the most readily utilized amino acid in crustaceans. In the amphipod, Echinogammarus stammeri (freshwater scud), phenylalanine is an important controlling factor in the leucine transport pathway (Berra et al., 2006)

In the present study, feeding of C. filosa by microalgae are rich saturated and unsaturated compound, total Polyunsaturated 18:2 (n-6 PUFA ) $\omega 6$ and Monounsaturated 18:1 (n-9 MUSA) $\omega 9$ fatty acids measured in the tissue of the field sample C. filosa was slightly less and higher the rate of total in the adults cultured and juveniles. Agreed with (Shaban, 2012) there is a clear significant difference in the fatty acids composition profile between the cultured and field Caprella mutica Caprellidea and the difference culture temperature in laboratory and samples collected from the field Oregon State, USA, . Emphasized that PUFA content is only one aspect for an estimation of the food quality, high content of 22-carbon PUFA in these invertebrates might reflect higher activity of their biosynthetic system (Sushchik et al., 2003). Long-chain n-3 PUFAs serve important roles in physiological processes (Brett and Müller-Navarra 1997) However; (Spector 1999) noted that although EPA is necessary for eicosanoid formation, DHA is likely considered the essential moiety of the n-3 family. (Sushchik et al., 2003) emphasized that PUFA content is only one aspect for an estimation of the food quality.

In the present study, total saturated fatty acids from C8:0 - C22:0 measured in the tissue of the field sample C. filosa was slightly less $(15.98 \mathrm{mg} / \mathrm{g})$ and higher in the adults cultured $(105.61 \mathrm{mg} / \mathrm{g})$ and 
juveniles $(99.17 \mathrm{mg} / \mathrm{g})$. Agreed with (Shaban, 2012) total saturated fatty acids from C14:0 - C18:0 of the field sample about $(30.27 \mathrm{mg} / \mathrm{g})$ but in adults cultured about $(75.638 \mathrm{mg} / \mathrm{g})$

\section{REFERENCES}

[1] Abe, H., Okuma, E., Amano, H., Noda, H., Watanabe, K., (1999):-Role of free-and-alanine in the Japanese mitten crab Eriocheir japonicus to intracellular osmoregulation during downstream spawning migration. Comp. Biochem. Physiol. A Mol. Integr. Physiol. 123, 55-59.

[2] Aoac (2000): Official methods of analysis of the association of official analytical chemist. $14^{\text {th }}$ ed. Washington DC, USA.

[3] Appadoo, C., (2008):- A Low Cost Amphipod-Based Feed for Rearing of Ornamental Aquarium Fish, Poecilia reticulata (Peters). Research Week 2007 - Special Issue - UoM Research Journal -Volume 13A

[4] Barnard, J.L. and Karaman, G.S. (1991): The Families and Genera of Marine Gammaridean Amphipoda (Except Marine Gammaroids). Records of the Australian Museum, 13(1\&2): 1-866

[5] Berra, E., Forcella, M., Giacchini, R., Parenti, P., (2006):- Leucine transport across plasmamembranes from the scud Echinogammarus stammeri (Amphipoda: Gammaridae). Int. J. Limnol. 42, 79-85.

[6] Brett, M.T. and D.C. Müller-Navarra, (1997):- The role of highly unsaturated fatty acids in aquatic food web processes. Freshwater Biol., 38: 483-499.

[7] Chen, X. Q. and Long, L. J. (1991): Research and production of live feeds in China. In: Fulk and Main (Eds.). Rotifer and icroalgae culture systems-Proceedings of a U.S.-Asian Workshop. Honolulu, Hawaii, 186-200.

[8] Dreosti, I.E. (2000):- Antioxidant polyphenols in tea, cocoa, and wine. Nutrition 16: 692-694.

[9] Duncombe, W. G., (1962): The colorimetric determination of longchain fatty acids in the 0.050.5 Mmole range. Biochem. J. 83, IIp

[10] Farag, R. S., Hallabo, S. A. S., Hewedi, F. M. and Bassyony, A. E. (1986): Chemical evaluation of Rape seed. Fette-Seifen Anstrichmittel. 88 (10): 391-397.

[11] Frankel, E. (1995):- Nutrinal benefits of flavonoid, International conference of food factor, Chemistry and cancer prevention Hamamatsu, Japan abstract, C6-2.

[12] Ghasemzadeh, A., Jaafar, H. Z. E., and Rahmat, A., (2010):- Antioxidant Activities, Total Phenolics and Flavonoids Content in Two Varieties of Malaysia Young Ginger (Zingiber officinale Roscoe) Molecules, 15, 4324-4333; doi: 10.3390/molecules15064324

[13] Glencross, B. D. (2009): Exploring the nutritional demand for essential fatty acids by aquaculture species. Rev. Aquacult. 1:71-124.

[14] Gornall, A. G., Bardawill, C. J., \& David, M. M. (1949): Determination of serum proteins by means of the biuret reaction. Journal of Biological Chemistry, 177, 751-766

[15] Guerra-García, J. M., Martínez-Pita, I. and Pita, M. L. (2004): Fatty acid composition of the Caprellidea (Crustacea: Amphipoda) from the Strait of Gibraltar. Sci. Mar. 68:501-510.

[16] Harborne, JB, Turner, B.L (1984):- Plant chemosystematics, Academic Press, London, 123.129

[17] Herzog, H.U., Liappis, N., (1987):-The plasma composition of larval Aeshna cyanea Müller-II. The effect of the nutritional state on the free amino acids. Comp. Biochem. Physiol. A Physiol. $87,47-52$.

[18] Just, J. (2002):- Review of Pseudopleonexes Conlan, 1982, with a new species from Australia (Crustacea: Amphipoda: pithoidae). Records of the Australian Museum, 54(1), 31-40.

[19] Karanova, M., Andreev, A., (2010):- Free amino acids and reducing sugars in the freshwater shrimp Gammarus lacustris (Crustacea, Amphipoda) at the initial stage of preparation to winter season. J. Evol. Biochem. Physiol. 46, 335-340.

[20] Leroy, D., Haubruge, E., De Pauw, E., Thome, J., Francis, F., (2010):- Development of ecotoxicoproteomics on the freshwater amphipod Gammarus pulex: identification of PCB biomarkers in glycolysis and glutamate pathways. Ecotoxicol. Environ. Saf. 73, 343-352 
[21] Lowry, J.K. \& Stoddart, H.E. (2003):- Crustacea: Malacostraca: Peracarida: Amphipoda, Cumacea, Mysidacea. In Beesley, P.L. \& Houston, W.W.K. (Eds), Zoological Catalogue of Australia, Vol. 19.2B, 531 pp, Melbourne: CSIRO Publishing, Australia.

[22] Maruthanayagam, C and P. Subramanian, (1999):- Biochemical variation of zooplankton population. J. Mar. Biol. Ass., India, 41 (1and2): 111-115.

[23] Matés, J.M., Perez-Gomez, C., de Castro, I.N., Asenjo, M., Marquez, J., (2002):- Glutamine and its relationship with intracellular redox status, oxidative stress and cell proliferation/ death. Int. J. Biochem. Cell Biol. 34, 439-458.

[24] Mente, E., Davidson, I., Karapanagiotidis, I.T., Fountoulaki, E., Nengas, I., (2010):- Amino acid analysis in the shore crab Carcinus maenas (Decapoda: Brachyura). J. Crustacean Biol. 30, 643650.

[25] Nageswara, R, I and Krupanidhi, G. (2001):- Biochemical composition of zooplankton from the Andaman sea, J. Mar. Biol. Ass. India, 43: 49-56.

[26] Nakamura Y, Watanabe S, Miyake N, Kohno H, Osawa T. (2003):- Dihydrochalcones: Evaluation as novel radical scavenging antioxidants. J Agri Food Chem 51: 3309-3312

[27] Peart, R. A. (2004):- A revision of the Cymadusa filosa complex (Crustacea: Amphipoda: Corophioidea: Ampithoidae) Journal of Natural History, 38, 301-336

[28] Peart, R.A. (2006):- A revision of Pseudopleonexes Conlan, 1982 (Crustacea: Amphipoda: Ampithoidae) with description of three new species from Australia. Zootaxa, 1344, 1-22.

[29] Peart, R.A. (2007a):- A review of Australian Cymadusa (Crustacea: Amphipoda: Ampithoidae) with descriptions of eight new species. Zootaxa, 1540, 1-53.

[30] Shaban, W, M, E.1.,(2012):- Life history, reproduction and rearing of Caprellid Amphipods: Its possibility to use as live feed in mariculture Ph.D. Degree in Marine Biology and Ichthyology (Marine Invertebrates) Zoology Department, Faculty of Science, Al Azhar University p214-218.

[31] Spector, A.A., (1999):- Essentiality of fatty acids. Lipids, 34: S1-S3.

[32] Sreepada, R.A., C.U. Rivonker and A.H. Parulekar (1992):- Biochemical composition and calorific potential of zooplankton from Bay of Bengal. Indian J. Mar. Sci., 21: 70-73.

[33] Stottrup, J. G., McEvoy, L. A. (2003): Live Feeds in Marine Aquaculture. Blackwell Scientific Publications Ltd, Oxford, United Kingdom, 318 p.

[34] Sushchika, N.N., Gladysheva, M.I., Moskvichovaa, A.V., Makhutovab, O.N., Kalachovaa G.S., (2003):- Comparison of fatty acid composition in major lipid classes of the dominant benthic invertebrates of the Yenisei river Comparative Biochemistry and Physiology Part B 134, 111122

[35] Taga, M. S., E. E. Miller and D. E. Pratt. (1984):- Chia seeds as a source of natural lipids antioxidants. J. Am. Oil Chem. Soc. 61:928-993.

[36] Tinder, P. (1969): Determination of blood glucose using an oxidase-peroxidase system with non carcinogenic chromogen. Ann Clin Biochem6: 24-29

[37] Tocher, D. (2010): Fatty acid requirements in ontogeny of marine and freshwater fish. Aquacult. Res. 41:717-732.

[38] Vengadeshperumal, N., P. Damotharan, M. Rajkumar, P. Perumal, S. Vijayalakshmi and T. Balasubramanian (2010):- Laboratory Culture and Biochemical Characterization of the Calanoid Copepod, Acartia southwelli Sewell, 1914 and Acartia centrura Giesbrecht, 1889 Advances in Biological Research 4 (2): 97-107

[39] Vogel, A. J. (1975): A text book of practical organic chemistery. $3^{\text {rd }}$ ed. P.. 969-971, English Language Book Society and Longman Group Ltd., London.

[40] Wainman, B and R.E.H. Smith, (1997):- Can physicochemical factors predict lipid content in phytoplankton Fresh Biol., 38(3): 571-579.

[41] Woods, C. M. C. (2009): Caprellid amphipods: An overlooked marine finfish aquaculture resource? Aquaculture 289(3-4):199-211. 
Biochemical Composition and Fatty Acid, Amino Acid Analysis of Cymadusa Filosa (Amphipod; Gammarids) in the Red Sea-Egypt

[42] Zollner, N. and K. Kirsch, (1962): Determination of the total lipid concentration in serum. Zentralbl Ges. Exp. Med., 135: 545-545.

[43] Zhishen, J., Mengcheng, T. and Jianming, W. (1999):- The determination of flavonoid contents in mulberry and their scavenging effects on superoxide radicals. Food Chemistry 64:555-559. 